\title{
POST-WAR URBANISM ALONG THE CONTESTED BORDER: SOME OBSERVATIONS ON KOPER/CAPODISTRIA AND TRIESTE/TRST
}

\author{
Neža ČEBRON LIPOVEC
}

COBISS 1.01

\section{ABSTRACT \\ Post-War Urbanism along the Contested Border: Some Observations on Koper/Capo- distria and Trieste/Trst}

The article presents observations from recent architectural historical research on the post-war construction of Slovene coastal towns. The urban planning concepts that formed the "Slovenian Coast" and followed the migration processes are explored. The solutions for the Slovenian Coast are compared with contemporary urban plans for Trieste, set in a larger historical framework. Certain interventions in "ethnically pure" locations (new settlements called 'borghi' on the Karst boundary surrounding Trieste; new construction in the Venetian core of Capodistria) are highlighted, and approaches in the design of new urban areas and two symbolic spaces of representations on both sides of the border are compared.

KEY WORDS: post-war urbanism, symbolic marking of space, Koper/Capodistria, Trieste/Trst, border

\section{IZVLEČEK}

\section{Povojni urbanizem ob sporni meji: Nekaj opažanj o Kopru/Capodistria in Trstu/} Trieste

Prispevek predstavlja opažanja iz nedavne arhitekturnozgodovinske raziskave o povojni izgradnji slovenskih obmorskih mest. Osredotoča se na urbanistične koncepte, s katerimi je bila oblikovana »slovenska obala« in ki so spremljali proces migracij. Rešitve na slovenski strani so z ozirom na širši zgodovinski okvir primerjane s sočasnimi urbanističnimi načrti za Trst. Poudarjeni so izbrani posegi v »etnično čiste« lokacije (ezulski borghi na tržaškem kraškem robu; pozidava beneškega Kopra), hkrati pa primerjani pristopi v oblikovanju novih mestnih predelov ter dveh simbolnih prostorov reprezentacij na obeh straneh meje.

KLJUČNE BESEDE: povojni urbanizem, simbolno označevanje prostora, Koper/Capodistria Trst/Trieste, meja

PhD in History, Research Assistant; Faculty of Humanities, University of Primorska, Titov trg 5, SI6000 Koper/Capodistria; neza.cl@fhs.upr.si 


\section{INTRODUCTION}

Urban planning and architecture, as the spatial representation of power, can also be read as the Althusserian ideological apparatus of the state (Rotar 1980). Both construction activities and demolition play an equally communicative role. Aside from the pragmatic effect of improving the living standard, they have the symbolic role of marking the space (Veschambre 2008). This issue is especially delicate in ethnically contested territories (ibid.; Hepburn 2004), and even more so when major ethnic restructuring occurs through population transfers.

Post-war periods, as moments of major redrawing of borders and restructuring, are a specific context of this issue - as is the case in the Istria region of the northern Adriatic, on the border between "democratic" Italy and socialist Yugoslavia. The post-WWII period was a time of slow yet radical transformation of this region, inhabited by Italian, Slovene and Croatian-speaking inhabitants. This "ethnic metamorphosis" (Purini 2010) is clearly discernible in the built environment. Visible changes can still be seen in the urban areas of present-day Slovenian Istria, especially in the city of Koper/Capodistria, at the same time a similar process was taking place just across the new border - in Trieste/Trst/Triest.

The present paper derives from recent doctoral research in architectural history on the post-war construction of Slovene Istrian towns, specifically that of Koper (Čebron Lipovec 2018). It presents an overview of the urban planning approaches on both sides of the border, with a focus on the urban development of Koper, while that of Trieste is used for comparison. The planning approaches are placed in a broader socio-political context. The "marking of space" through demolition/preservation, as proposed by Veschambre (2008), is used as the main interpretative tool. The data for Koper are taken from archival documents on urban planning (Koper Regional Archive), while the data on planning in Trieste are taken from a selection of existing studies (Klabjan 2017; Marin 2012; Volk 2003; Pozzetto 1997).

\section{FIRST POST-WAR URBAN PLANS IN A DIVIDED REGION}

In the period after World War II, during the creation of new nation states, population transfers were a general approach in enabling this process, and at the same time, at least formally, preserving peace (Corni 2015). As an ethnically mixed border area between the emerging Yugoslav socialist state and the capitalist West, Istria presented a specific challenge in drawing the new border between Italy and Yugoslavia. The Free Territory of Trieste (FTT) (1947-1954) was the first mechanism used to address the issue. The contested area was organised as a temporary, multinational buffer state, with its own Statute, and divided in two zones: Zone A in the western part around Trieste was governed by the Allied Military Government, while the eastern part, extending from Koper to the Mirna River, was governed by the Yugoslav 
military administration. As Pirjevec (2008) explores in detail, in the decade between 1945 and 1954, several scenarios were drawn up by the international political forces in charge. Supporting the Italian ambitions, the American and English politicians promoted the annexation of the entire FTT to Italy; conversely, the Russian scenario aimed at integrating it into Yugoslavia, with options to keep Trieste as an autonomous zone. The negotiations also led to the proposing of a mosaic division of the land according to ethnic affiliation, which implied that the southern outskirts of Trieste, in the area between Noghere/Oreh and Žavlje/Zaule, would become Slovenian (Yugoslav), and function as a corridor to the sea, while the small medieval cities of Koper/Capodistria and Izola/Isola would be annexed to Italy, so only the urban outskirts would be granted to Slovenia (Rogoznica 2011: 291; Pirjevec 2008: 460-461; Beltram 1986: 39), somewhat similarly to the Gaza Strip. The dilemma was resolved by the London Agreement in 1954, through which Zone A was annexed to Italy and Zone B to Yugoslavia.

Simultaneously with the key events in northern Istria, other contested spaces around the world were undergoing radical transformations: the 1948 establishing of the State of Israel on Palestine territory; and Chandigarh, the new capital of Eastern Punjab region in India, which was built after the split with Pakistan. Major destroyed cities and capitals of Europe were undergoing reconstruction, and new cities and quarters were built, imbued with symbolic meaning. The best-known is the Karl-Marxalle, later Stalinalle, in Berlin. For Slovenia, the "new Gorica", Nova Gorica, built on the upper Slovenian-Italian border, was significative, since the old Gorica had been "aggressively torn out [of Slovene hands] by the western imperialists", in the words of Slovene press (Ramšak 2015: 75), and it remained part of Italy. This representative urban planning project was started in 1947: the new town was supposed to "shine" across the border (Ukmar 1993: 22). The plan was designed by Edvard Ravnikar, the leading new Slovenian modernist architect, and a pupil of Le Corbusier. Yet, while Nova Gorica was built from scratch, on Slovene national and ethnic territory, the context of the Istrian cities, lying on the maritime part of the same border, was drastically different. The "new Koper" grew atop a very rich historical and multi-ethnic environment.

\section{First Regional Plan for Zone B of the Free Territory of Trieste}

In 1948, while working on Nova Gorica, Ravnikar was also involved in the drafting of the first conceptual regional plan for Zone B of the FTT, exhibited in 1950 at the economic exhibition in Koper (Krečič et al. 1996: 14).

The plan is an expression of the desire to strengthen the links between the coastal towns and their eastern hinterland, envisaging the Slovenian and Yugoslav objective to annex the area. As opposed to later plans, the focus of development was not the city of Koper, but Izola, a town with a strong industrial infrastructure, and 
Sečovlje, an area with a charcoal pit. The plan followed the communist principle that new towns should develop next to major industrial sites.

At the time, no urban plan yet existed for Koper, except for some housing in the outskirts (Semedela/Semedella). There were plans to expand the city, but the uncertain fate of the FTT hindered any action. The potential scenarios for the division of the territory influenced the locations of new housing: the possibility of having to cede the cities of Koper and Isola to Italy dictated the decision to build new housing around Koper on the terraferma, i.e. in Semedela, Škocjan and Bertoki (Beltram 1986: 39; Rogoznica 2011: 291). Thus, large-scale planning was begun only after the London Agreement.

\section{Post-War Planning of Trieste}

Simultaneously, in 1949, a new urban plan was also designed for Trieste. It was conceived after the first free local elections won by the democratic Christian engineer Gianni Bartoli, a defender of the city's Italian identity (Cardin 2004: 22), and was based on the decision, adopted by the Allied administration in 1947, that the focus of development in Trieste consist in expanding the industrial zone on the eastern outskirts, around the village of Žavlje (Di Biagi 2004: 14). This area, historically the site of saltpans, had been foreseen as the main industrial zone even in earlier plans, especially those of the architect Grassi in 1934 (Marchigiani 2004: 87; Marin 2012: 617-618). Bartoli's plan was thus developed on these bases but had more dimensions. In pragmatic terms it aimed at the organic growth and management of the city, but it was also a symbol of Bartoli's vision of the "grande Trieste" (Basso 2004: 37). A prominent role in this planning process was taken over by the renowned architect and urban planner Max Fabiani.' In 1953, Fabiani got in touch with Bartoli and exhorted him to demand "the right and the responsibility to make it clear what [the city of Trieste] needs to ensure its existence" (Pozzetto 1997: 377). He pursued the idea of a free and modern, market- and industry-oriented development of Trieste, for which a large radius of at least $40 \mathrm{~km}$ was needed. In this plan, Koper would become (or remain) "merely a suburb of Trieste" (in Di Biagi 2004: 15). In his vision, the city and its hinterland with the Istrian towns needed to be integrated into the same state, or at least under the same administration.

$1 \quad$ Architect and urban planner Max Fabiani (1865-1962), originally from Kobdilj (Štanjel) on the Slovenian Karst, was one of the most influential architects and urban planners of the Austro-Hungarian empire, a collaborator of key Austrian theoretician of urban planning Otto Wagner, and professor at the Technical University of Vienna. Aside from his architectural and urbanistic oeuvre, which spans from Vienna to Ljubljana and Trieste, he also produced reconstruction plans for towns in the Friuli region that had been damaged during World War I (Pozzetto 1997). 
Fig. 1: Plan for the development of the Trieste metropolitan area, architect Max Fabiani, 1954

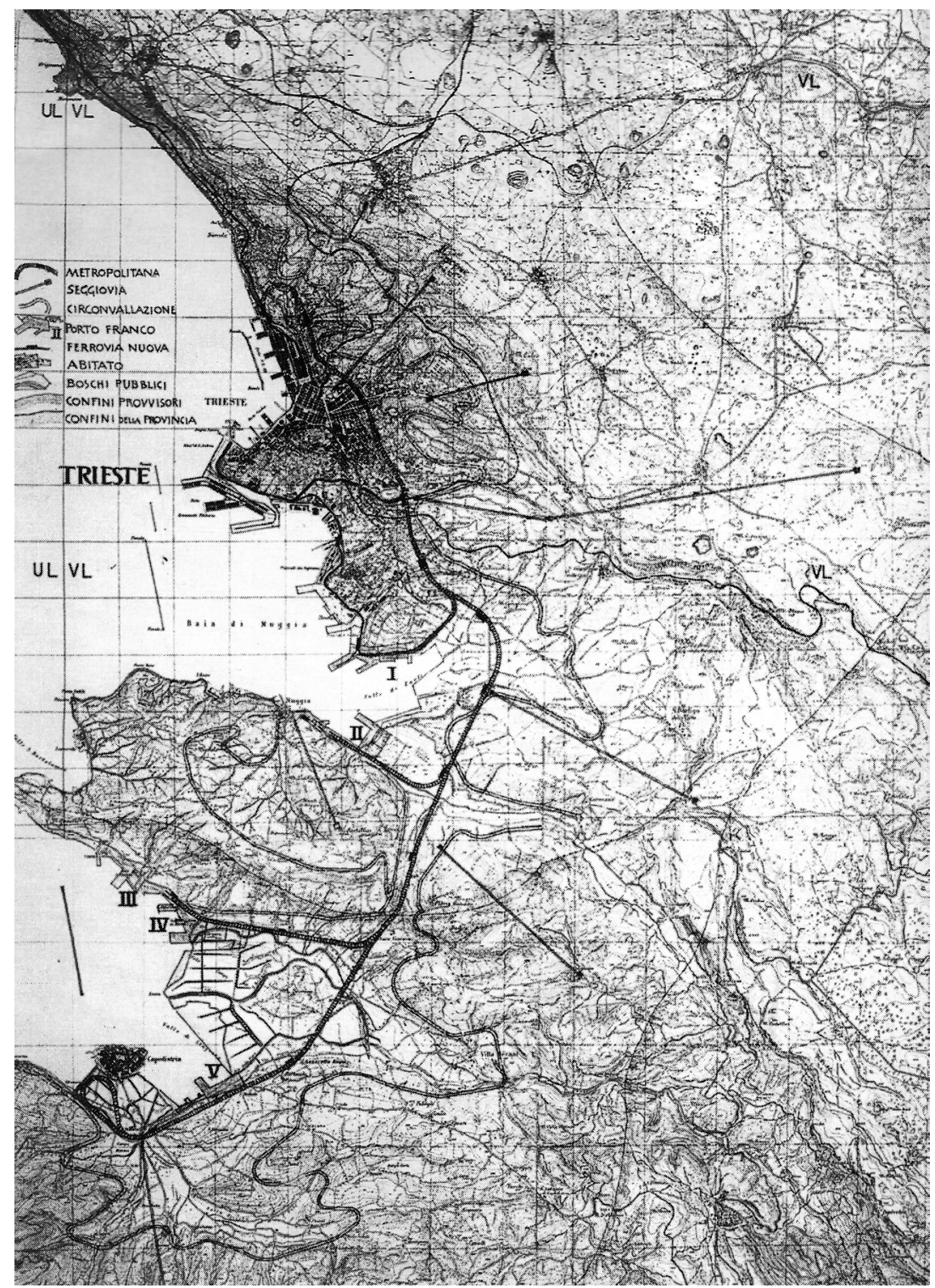

Source: Pozzetto 1997; kept in the Archive of Mayors'Secretariat of Trieste

Designed in 1954, the plan conceived Trieste as a città territorio, a metropolitan area for 600,000 inhabitants, extending over a 50-60 km strip between the mouth of the Soča River on the west and the city of Piran on the east. The transport network was a central issue: Fabiani foresaw a hierarchical backbone of a metropolitan railway running to Koper, but also planned funiculars that would connect the city transversally with the hinterland on the Karst boundary (Pozzetto 1997: 378-379; Basso 2004: 
38-39). This broad vision of development was part of a larger conceptual plan that Fabiani had been developing for the northern Adriatic region since the early $1900 \mathrm{~s}$ (Pozzetto 1997: 369-371). Fabiani's plan for Trieste was never realised, except for certain aspects of the transport network (ibid.: 378-379).

However, the idea to link the city and the Karst boundary was realised differently. Even before Fabiani's plan, the Julian and Dalmatian refugees' assistance board (Opera per l'assistenza ai profughi giuliani e dalmati, OAPDG) was created in 1952, with the task to provide housing for those refugees, built mainly on the outskirts of Trieste, on Slovene ethnic territory in the Karst villages, and in neighbourhoods that had strong Slovene populations. ${ }^{2}$ The first part to be settled by refugees, and the most transformed ethnically, was the north-western part of the Karst boundary (Volk 2003: 296; 2004: 316-317), namely Villaggio del Pescatore (1952) in the municipality of Devin-Nabrežina/Duino-Aurisina, next to the town Štivan/San Giovanni al Timavo, and Borgo San Mauro next to the nearby town of Sesljan/Sistiana. Others followed: the settlement of Campo Romano in Opčine/Opicina (1953); the settlement of SS. Quirico e Giulitta in Križ/St. Croce (1953), and the settlement of Borgo San Nazario on the outskirts of Prosek/Prosecco (1955); a total of 14 new settlements or neighbourhoods were built (Volk 2003: 302-307).

Fig. 2: Map of new settlements (borghi) for Istrian and Dalmatian refugees in the area of Trieste

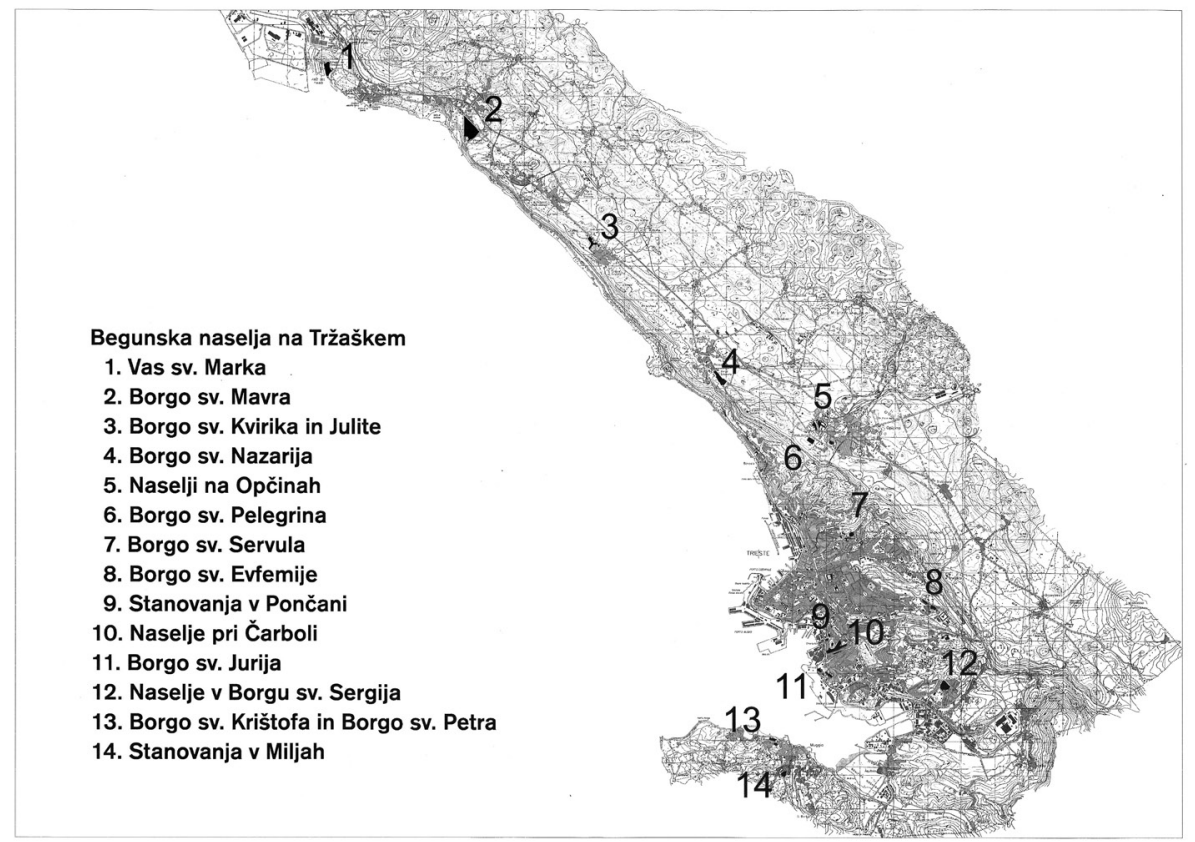

Source: Volk 2003

2 Fundamental research on the settlement of Istrian and Dalmatian refugees in the area of Trieste and the ethnic bonification of the Trieste area was conducted by Sandi Volk $(1997,2003,2004)$. 
The post-war expansion of Trieste with new settlements for refugees turns out to have been a clear case of the "national bonification", or Italianisation, of the larger Trieste area (Volk 1997, 2003, 2004). The rural periphery and suburban quarters of Trieste, with a majority Slovene and/or proletarian population, was reputed by the Italian authorities to be an area of "leftist Slovenian communities", derogatively termed "slavokomunisti" or "anti-Italian forces" (Volk 2004: 316-317). The strongest bonification process occurred in the municipality of Devin-Nabrežina/Duino-Aurisina, so as to ensure the military-strategic control of the transport corridor, since here the distance between Yugoslavia and the sea was barely $3 \mathrm{~km}$ as the crow flies (ibid.). Some of the borghi operated as physical and social barriers between historically Slovene villages, which became parts of the city: these included the new settlement of Chiarbola/Čarbola, built between the quarter of Sv. Jakob/San Giacomo and Škedenj/ Servola. These spatial planning interventions signified long-term social changes: upon the settlement of the new inhabitants a new pro-Italian electoral body was formed, and new Italian schools were created (ibid.). The identity of the area of the Karst boundary began to change.

\section{URBAN PLANNING AFTER 1954: A NEW REGIONAL CAPITAL}

According to the new border drawn by the London Agreement, the Slovenes lost the long-awaited Trieste, while the Italians lost the Istrian towns, and as a result numerous metamorphoses took place on both sides of the border.

\section{The Metamorphosis of the Northern Istrian Towns}

During the period of the FTT, the prevailing ideal of the leading local political party, the SIAU-UAIS (Slovensko-italijanska antifašistična unija - Unione antifascista italiano-slovena), was that of fratellanza, brotherhood between the Italian and Slovene nation in Istria. Hence, a certain level of coexistence between the two ethnicities was sought; considering the temporary role of the FTT, the economic transformation from private enterprise to public was not fully realised, and small merchants, mainly of Italian origin, were still allowed to trade (Rogoznica 2011). This attitude was perceived by the central Slovenian political authorities, namely the League of Slovene Communists (LSC), as ideological incompliance. Just before the annexation of Zone B to Yugoslavia, in July 1954, Boris Kraigher, president of the Executive Committee of the Slovenian National Assembly, expressed a clear critique of the attitude of the party leaders in Zone B about the national issue: "We still haven't carried out the revolution that we should have in 1945, that this is a Slovenian territory. I still have the impression that this is a territory under occupation!" (quoted in Rogoznica 2011: 301-302). 
After the annexation, this "failed revolution" was gradually realised. The local political functionaries and professional staff in Istria were removed: the internationalist-leaning leaders open to collaboration with the pre-war population were replaced by politically more suitable new representatives ${ }^{3}$ of the "new hard line" ${ }^{\text {"4 }}$ of opponents of fratellanza (Hrobat Virloget 2015: 541). A similar ideological shift from the internationalism of the FTT to the social patriotism of Yugoslavia occurred in Rijeka/ Fiume in the early post-war years (Abram 2017: 5-8), where the "commitment to the promotion of national identity could overshadow the wider process of building the socialist society" (ibid.: 9). The shift in ideological system as well as the process of creating a mono-national state provoked a progressive yet tectonic shift in the population of the Istrian coastal urban areas (Titl 1961; Kalc 2015; Hrobat Virloget 2015). The pre-war inhabitants of the area, whose mother tongue was mainly Italian or the Istro-venetian dialect, started to emigrate from the region, and new inhabitants from inland Slovenia started to immigrate - first from nearby areas (Trieste, Brkini, northern Primorska), and later also from central Slovenia and Štajerska, and finally, from the 1960s on, mostly from other Yugoslav republics (Kalc 2015). By 1956, the moment of "normalisation" (Titl 1961: 22), more than $90 \%$ of the pre-war population of the three northern Istrian towns had left the area, and new inhabitants had resettled it. As a non-south-Slavic minority, the remaining Italians, despite their status as an official minority, became marginalised in the public sphere.

The new borderline split the land "inorganically" into two parts and separated Trieste from its natural hinterland. The new political and geographical reality of northern Istria required a new vision of economic development. Immediately in late 1954, the Slovene authorities introduced large-scale industry (the Tomos motorcycle factory), and in 1957, even more significantly, established the Port of Koper (Terčon 2015). Another salient economic field was tourism, developed strategically as a key source of foreign currency (Šuligoj 2015: 22; Križman 2005: 121).

In 1955, arriving in step with the "political hard line", the architect Edo Mihevc ${ }^{5}$ was given the most influential role in urbanism as president of the new Urban Planning Council in the District of Koper. In a short time and in large proportion, the

3 The secretary of the local committee of the Communist party during the period of Zone B, Julij Beltram, was replaced in 1955 by Albert Jakopič - Kajtimir, and the new president of the District of Koper, Albin Dujc, took office along with him (Čebron Lipovec 2018).

4 At the same time, Emil Smole, the first Slovene director of the museum in Koper, who had been in charge of the protection of monuments, was sent away and replaced by an ideologically more appropriate new director (Plesničar Gec 2002: 106).

5 Edo Mihevc (1911-1985) was one of the leading figures of post-war modernist architecture in Slovenia, as he was not only a professor at the School of Architecture in Ljubljana but also an influential figure within the Slovene Communist elite. He is known for having introduced some representative modernist building types in the Slovenian context (the Metalka skyscraper in Ljubljana; 'Kozolec' housing as a version of Le Corbusier's unité d'habitation, also in Ljubljana; the new Cultural Centre of Slovenes and Slavs in Trst/Trieste), but especially as the architect of the "Slovene Coast", as he designed the new comprehensive urban plan and introduced tailor-made regionalist architecture in the coastal region. 
northern Istrian urban areas acquired a completely new look. According to Mihevc, the newly built environment was conceived so as to preserve the visual coherence and continuity in the settlement of the region while allowing its modernisation (Mihevc 1963: 42; Mihevc 1964: 9). Nevertheless, especially in the case of Koper, not continuity but rather a radical reconstruction was pursued.

\section{The New Regional Capital}

Having lost Trieste, the coastal region needed a new capital. The choice of the capital was linked to the location of the new port - the "Slovenian window to the sea". After discussions among politicians and planners, in 1955-1956, the final location for the port was chosen in Koper, so the comprehensive development of the "Slovene Coast" was started, beginning in 1956. The key planning document, "Regional Plan of the Slovenian Coast", was developed by Edo Mihevc in 1959-1963. Tourism was the main economic field for the region, while each town was assigned its own role: Koper as the administrative and industrial centre; Izola as industrial and fishing centre; and Piran and Portorož as tourism centres.

Fig. 3: Regional Plan for the Slovenian Coast, Edo Mihevc, 1963

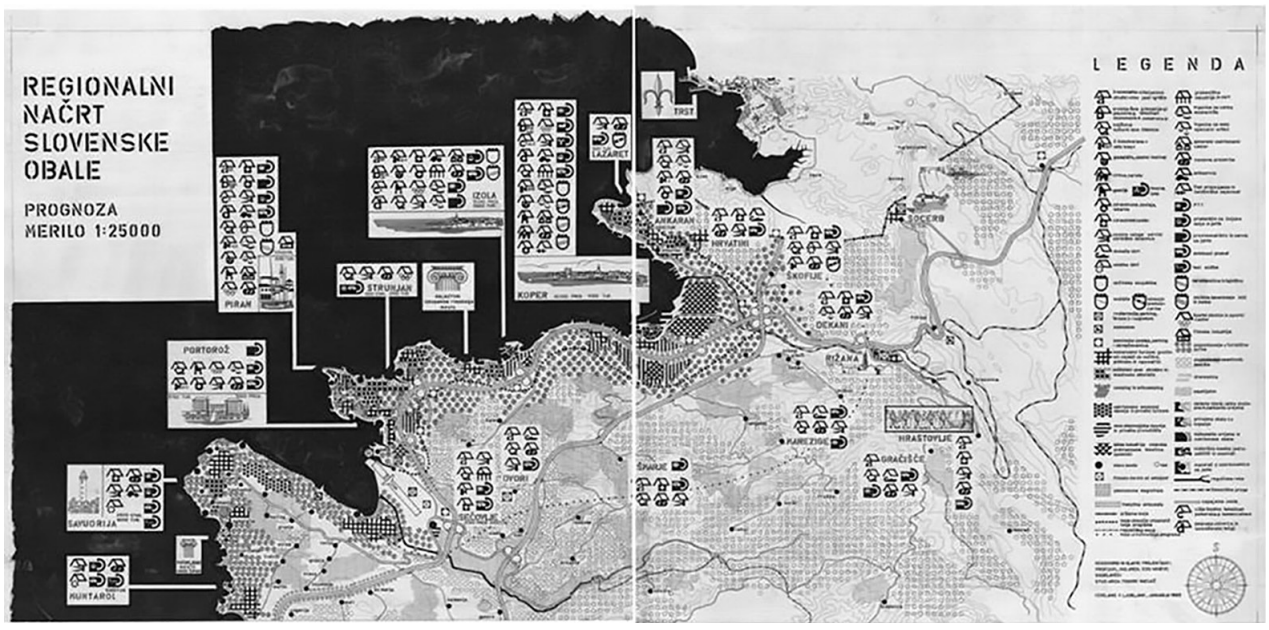

Source: SI PAK KP 865

Mihevc, as the president of the Urban Planning Council, had the political power to propose a comprehensive plan for the entire region that matched the new socialist economic and social ideals. In addition to the central task to define the functions of the towns, his major input consisted in two key aspects: he provided a comprehensive plan for developing the traffic network along the coast, and more importantly he created a common image for the Slovene Coast, devising the idiosyncratic 
architectural idiom of "progressive Mediterranean architecture". This related to local traditional architecture, by attaching a traditional image to modern building types (blocks of flats and row-houses), using pitched roofs, vertical windows, white window frames and wooden shutters, pergolas, etc. This traditionalist architectural idiom, the architect claimed, aimed at overcoming the political and ethnic divisions in the (multi-ethnic) region (Mihevc 1963: 42). The overall result of the plan's approach was a rather homogeneous, modern, yet locally anchored image of the coastal part of the region. In fact, the main building activities were concentrated along the coast and in the urban areas, leaving the rural hinterland mostly untouched. The most changed was the city of Koper, following the Mihevc's plan made between 1959 and 1961.

However, Mihevc's designation of a "regionalist" idiom seems to have been also a reaction to the earlier plans for Koper, prior to 1956, which promoted a more clearly modernist aesthetic, and which would have been clearly discernible from the rest of the built environment - a visible sign of change. The first post-1954 urban plan for Koper was drafted by Nikolaj Bežek, Ravnikar's colleague, between 1954 and 1957, and foresaw a satellite-type expansion of the urban area on the terraferma, especially in Semedela, following Scandinavian examples of neighbourhoods, and leaving the historic core untouched. Mihevc integrated a great deal of Bežek's plan into his later plans for Koper $(1961,1963)$, especially for Semedela, but with a clear difference in aesthetics: Bežek's modernism was replaced by Mihevc's traditionalism.

Fig. 4: Urban Plan for Koper, Edo Mihevc, 1961

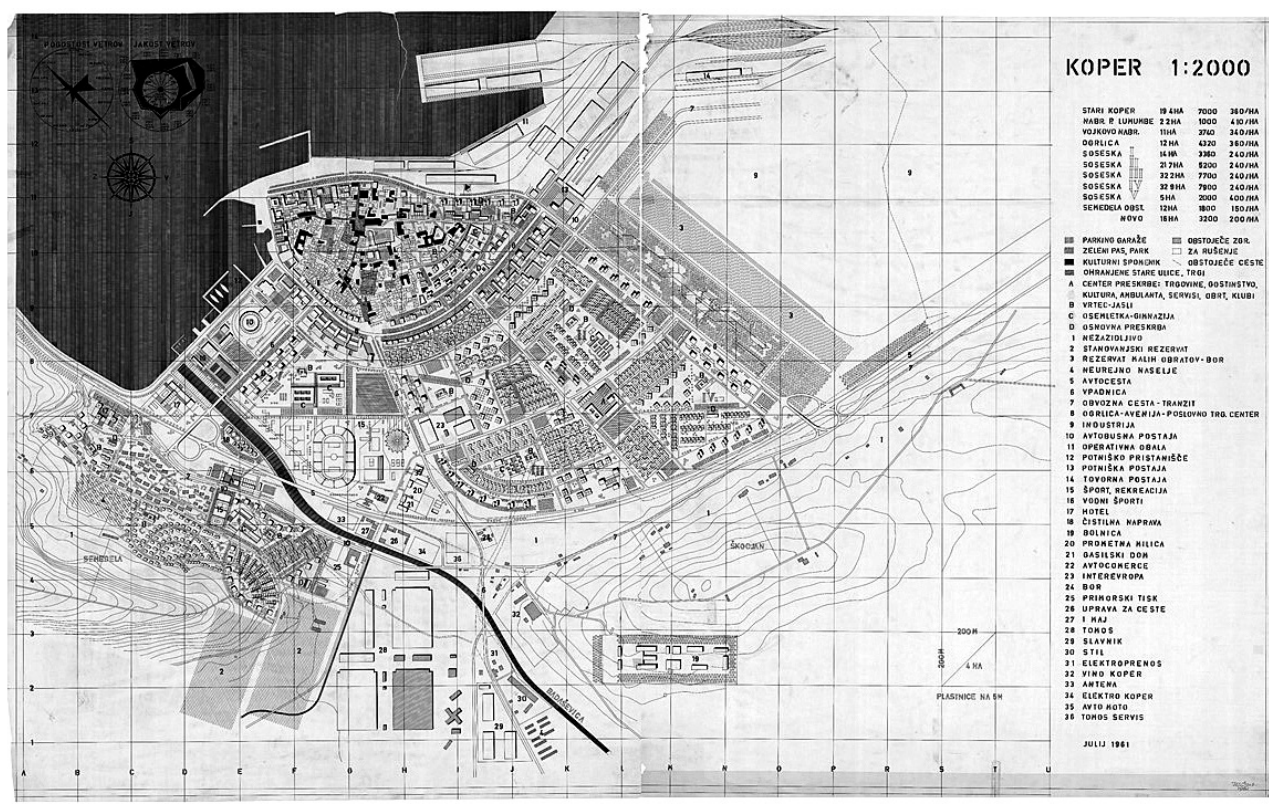

Source: SI PAK KP 865 
Fig. 5: View of the streets in the new neighbourhood of Semedela on the outskirts of Koper, architect Edo Mihevc, 1960s

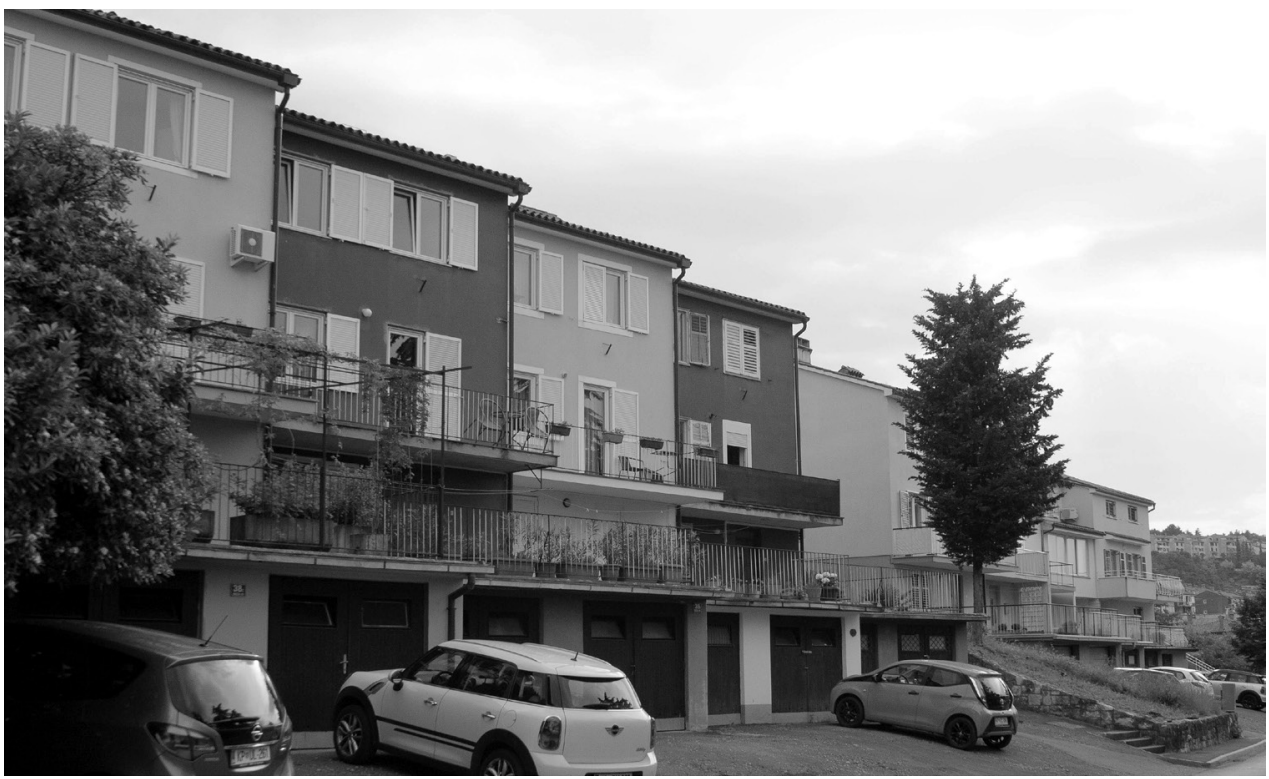

Photo: Neža Čebron Lipovec 2018

While the port was being constructed in Koper, industrial plants were being built in the eastern suburb of Trieste, in Žavlje (Marchigiani 2004b: 89). Along with them, a new workers' (and refugees') settlement, called Borgo San Sergio, was growing. The task was given to Ernesto Nathan Rogers, ${ }^{6}$ one of the most important Italian architects of the time and an influential theoretician within the context of CIAM (Mumford 2000), also originally from Trieste. Between 1955-1956, Rogers, collaborating with local architects, ${ }^{7}$ proposed an organically developed, three-zone settlement with diversified, regionalist building types.

6 Not only a key theoretician of CIAM, Rogers also was the chief editor of one of the most influential international architectural reviews, Casabella-continuità, where he published several articles and editorials promoting his theories on linking the existing built environment with new construction. Mihevc was a reader of the review, and he published his regional plan for the Slovenian Coast in it in 1963 (Mihevc 1963).

7 The co-author of the project was the municipal engineer Aldo Badalotti (Marchigiani 2002: 328-329). 
Fig. 6: View of the streets in the Borgo San Sergio, built according to the plan by Ernesto Nathan Rogers and Aldo Badalotti, 1956-1960

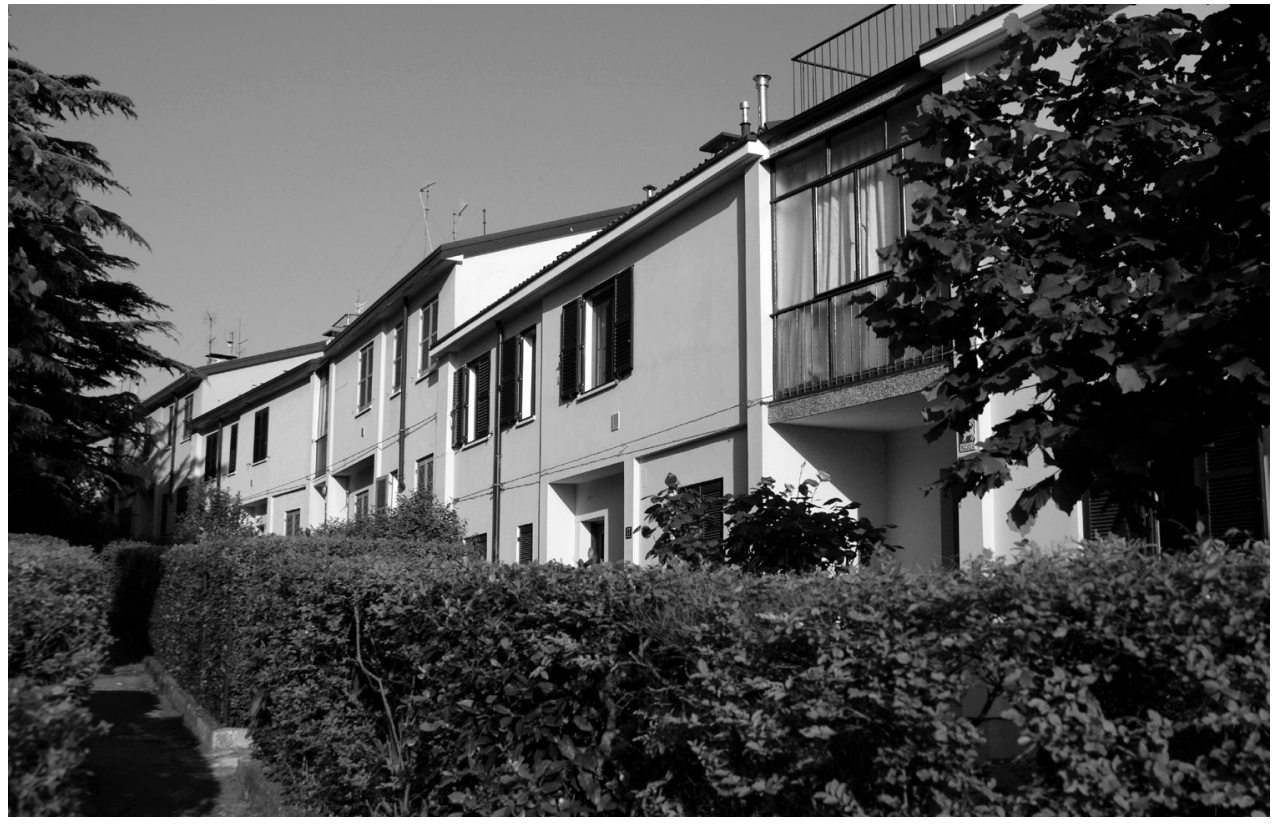

Photo: Neža Čebron Lipovec 2018

The plan had only been partially executed by the early 1960s, yet it encapsulated much of the spirit of the time - the architectural neorealist trends of the INA-casa national project (Di Biagi 2001) and the more novel architectural concepts of humanised space. Similarly to Mihevc's plans for the Semedela neighbourhood in Koper, this new settlement was designed organically, with alternating blocks of flats and row-houses with pitched roofs, pinkish facades, a main square with a community centre, all immersed in greenery. It seems that the two architects on both sides of the border were aiming at similar objectives - to create a humanised modern environment that related to the genius loci.

The building activities in Trieste mainly concerned new settlements on empty lots - but on Slovene ethnic territory. Conversely, especially in Koper, a large part of the new urban structure was placed on top of the existing historical fabric, following Mihevc's plan. Again, the comparison with the prior Bežek's plan (1954, upgraded in 1957) regarding the historic core is apposite: Mihevc foresaw a radical demolition and reconstruction of the historic core, surrounding it with a new city wall of ten-storey skyscrapers. This plan was only partially realised. With regard to the historical framework, we note that Bežek's plan had been prepared during the time of the internationalist local political leaders, whereas Mihevc enters the scene from 1956 on, together with the hard-line Communists promoting socialist patriotism. Bežek's minimalist approach towards the historic centre - the topos of the collective memory of the former 
inhabitants - hints at the architect's sensitivity to and respect for history, and thus to the multicultural nature of the historic town. Conversely, Mihevc's approach shows an absence of such respect, and it can be read as an intentional act of destruction: in practical terms it concerned the renewal of areas with "unhealthy" buildings, but in symbolic terms it eliminated the symbolic markers of the city's Venetian and Romance past.

\section{LANDMARKS OF “ETHNIC BONIFICATIONS"}

While the Karst around Trieste was undergoing strong ethnic bonification, an inverse process was happening on the Slovenian side of the border - the population, content and image of the historic Istrian towns were changing. New, modern suburbs were rising next to the historic Venetian towns. Where before the war the Capodistrian urban farmers called paolani had been cultivating vineyards, in 1954 new industrial plants such as the Tomos factory in Olmo arose rapidly. So, while the Italian national identity and the capitalist-bourgeois ideal was gaining strength in multicultural Trieste, a new Slovene and Yugoslav socialist society was being established in the Slovenian coastal towns.

\section{Demolitions as Symbolic Negations}

The internationalist and multi-ethnically oriented ideal of "fratellanza", typical of the FTT period and documented by memorial plaques and monuments to the antifascist struggle in both Italian and Slovene, ${ }^{8}$ was replaced after 1954 by a discourse of socialist patriotism, stressing Slovenian sovereignty and the presence of socialist society, as if in response to Kraigher's call in 1954 to complete the revolution.

Koper became the central representational space in the contested area of northern Istria. As a result, the city underwent numerous radical interventions, among which the most pronounced was a ten-storey high-rise known as the "Tomos skyscraper" in the Belveder neighbourhood in the historic core of Koper, built to house workers at the Tomos factory. Coloured red, with white and blue window-frames, it recalled the colours of the national flags - as if to comply with the Stalinian motto to build architecture "national in style, socialist in content". This most visible modernist

8 During the Zone B period, memorial plaques (still visible on Tartini Square in Piran, and in the city centre and outskirts of Izola) and monuments were erected in commemoration of the joint Slovenian-Italian antifascist struggle. The most explicit of all is the still-standing bust of Pier Paolo Vergerio il Giovane, the Protestant Bishop of Koper in 16th century and a friend of the Slovene Protestant Primož Trubar, which was promoted as precursor and symbol of the fratellanza ideal. However, these monuments were relatively few in number; after 1954 two more plaques were erected in Koper, and one sculptural monument in Bertoki/Bertocchi in the mid-1970s, in the period of the Osimo Agreement (Hrobat Virloget, Čebron Lipovec 2017). 
landmark of Koper was built between 1957 and 1960, despite professional criticism. It was set on the northern edge of the medieval core and became the visual accent of the new Belveder neighbourhood and Koper's skyline. A vast portion of the historical fabric had to be demolished, including the abandoned former Gregorite convent, a symbol of Slavic presence in the city due to their liturgy in Slavic languages (Žitko 2012). As a symbol of the powers in the past, despite its national importance, it was replaced by a symbol of the new socialist Slovene society. The Tomos building was integrated into the later plan for Koper in which the entire perimeter of the historic town was to be demolished and surrounded by a "necklace" of high-rises as a modern city wall. Had the plan been realised in its entirety, most of the historical fabric, namely the vernacular housing, would have been destroyed, and only four main streets would have been preserved as representative sites.

Such a destructive approach can be attributed to the modernising spirit of functionalist architecture that promoted removing "unhealthy" old buildings and replacing them with modern free-standing buildings with better ventilation, sunlight, and greenery (Mumford 2002). But considering the contested character of post-war Istria, these demolitions can also be read as symbolic actions. Following Halbwachs' theory (2001 [1950]) on collective memory, the built environment is the material reference into which collective memory is inscribed. Since the former inhabitants of Koper had departed and the buildings from the pre-1945 era were being demolished, the collective memory and presence of its former inhabitants was also being erased, so the demolitions can be read as "symbolic negations" of the place's identity (Veschambre 2008: 94). After 1955, with the new local hard-line political leaders who promoted Slovenian national discourse against that of fratellanza, Kraigher's "unfinished revolution" was in fact being carried out. By late 1956 the emigration of the pre-war local population had ended, and the three towns remained largely empty for Slovene and Yugoslav newcomers to resettle them. On the urban planning level, this was achieved through Mihevc's plans. His approach was dismissed in 1967 after a public tribunal organised by Slovenian specialists in conservation, that untangled the "revolutionary" stamp of Mihevc's approach in the historic core of Koper: "I think this is not a renewal of the city, but rather a revolution of the city. We have de facto inherited the materiality of the town, we have changed its population, its meaning and its programme" (architect Savin Sever, quoted in Bernik 1967: 82).

The large demolitions in the historic town of Koper carried out after 1957 can thus be interpreted as the erasure of the former (Venetian, Italian) identity of the newly acquired Slovenian town, and thus as a tool of the "(national) revolution" or "Slovenisation", or "Yugoslavisation" of the area. A similar process of "intense Croatisation" has also been identified in the post-war period in the city of Rijeka/Fiume (Abram 2017: 6), while similar spatial metamorphoses are known from the Südeten area on the Czech-German border (Elman Zarecor 2014: 69; Wingfield 2000: 254-256), the Polish-German border area, and from Kaliningrad/Königsberg (Sezneva 2003). 
In terms of changing the city's cultural and ethnic identity, the interventions in the historic core of Trieste in the 1930s hint at a similar approach. Major symbolic landmarks (Victory Lighthouse; Oberdan Square; Casa del Fascio and the restoration of the Roman amphitheatre and the University building) were realised as intentional markers of space (Klabjan 2017), but entire historic vernacular quarters of Trieste were also planned to be or were in fact demolished and replaced by monumental modern Stile Littorio buildings (as in the designs of Camillo Jona) so as to conceal the typical image of the Habsburg emporium (Marin 2012: 619) and "Italianise" the city (Purini 2010: 101-107), but also to "fascistise" it (Klabjan 2017). The same "reconstructive", de facto "fascistising" approach in the historical urban core was also used during the Fascist period in South Tyrol, in the city of Bozen/Bolzano (Steinacher 2013). Nevertheless, in Trieste the process seems to have started already in the Habsburg period, before WWI, with public statues and street-names marking the Italian element, and was perpetuated in the post-war and post-Fascist period (Klabjan 2017).

\section{Organised Creation of Identity through Symbolic Landmarks}

Along with the demolitions and new construction, the renaming of streets and squares also took place according to the new mono-national memory discourse: in Trieste in 1920s-1930s, and in Koper gradually from the Zone B period onwards. The three elements (demolition, new construction, new street names) functioned as a form of organised social forgetting, in parallel with organised social remembering and the creating of a new memory (Wingfield 2000).

As the overview of the development of urban and regional planning showed, the processes on both sides of the Slovenian-Italian border were relatively parallel. The choice of developmental focal points on both sides can be identified as a strategy of material but especially symbolic appropriation through the visual marking of the space (Veschambre 2008). From this point of view, the urban planning strategies on both sides of the border can be read as a symbolic competition in the marking of space between the two ethnic groups: Italians on Slovene ethnic territory, now officially in Italy, and Slovenes on Italian ethnic territory, now officially in Yugoslavia. Decoding the official national discourses, we can see in the urban planning on both sides of the border that each of the ruling groups occupied the territory of the other, silenced the members of the other group (the Italian minority in Slovenia and Slovenian minority in (taly) ${ }^{9}$ and at the same time symbolically inscribed its own hegemonic position into the built environment. On the Italian side of the border, this

9 Nevertheless, in the Slovene villages on the Karst boundary, monuments to the antifascist struggle were being erected in phases, staring in the first post-war years and leading into the 1960 s and 1970s, and both promoted the antifascist struggle but at the same time, through the inscriptions in the Slovene language, marked the Slovenian ethnic territory (for an indepth analysis see Klabjan 2016). 
process was a continuation of the Fascist approach, symbolised by the Sacrario di Redipuglia (Dato 2013; Klabjan 2017: 14). Yet, the post-war period built its symbolic landmarks as well, and hence the symbolic duel of landmarks is best discernible in two spatial dominants.

Fig. 7: Landmark - Tomos skyscraper, built in the historic core of Koper/Capodistria, architect Edo Mihevc, 1957-1960

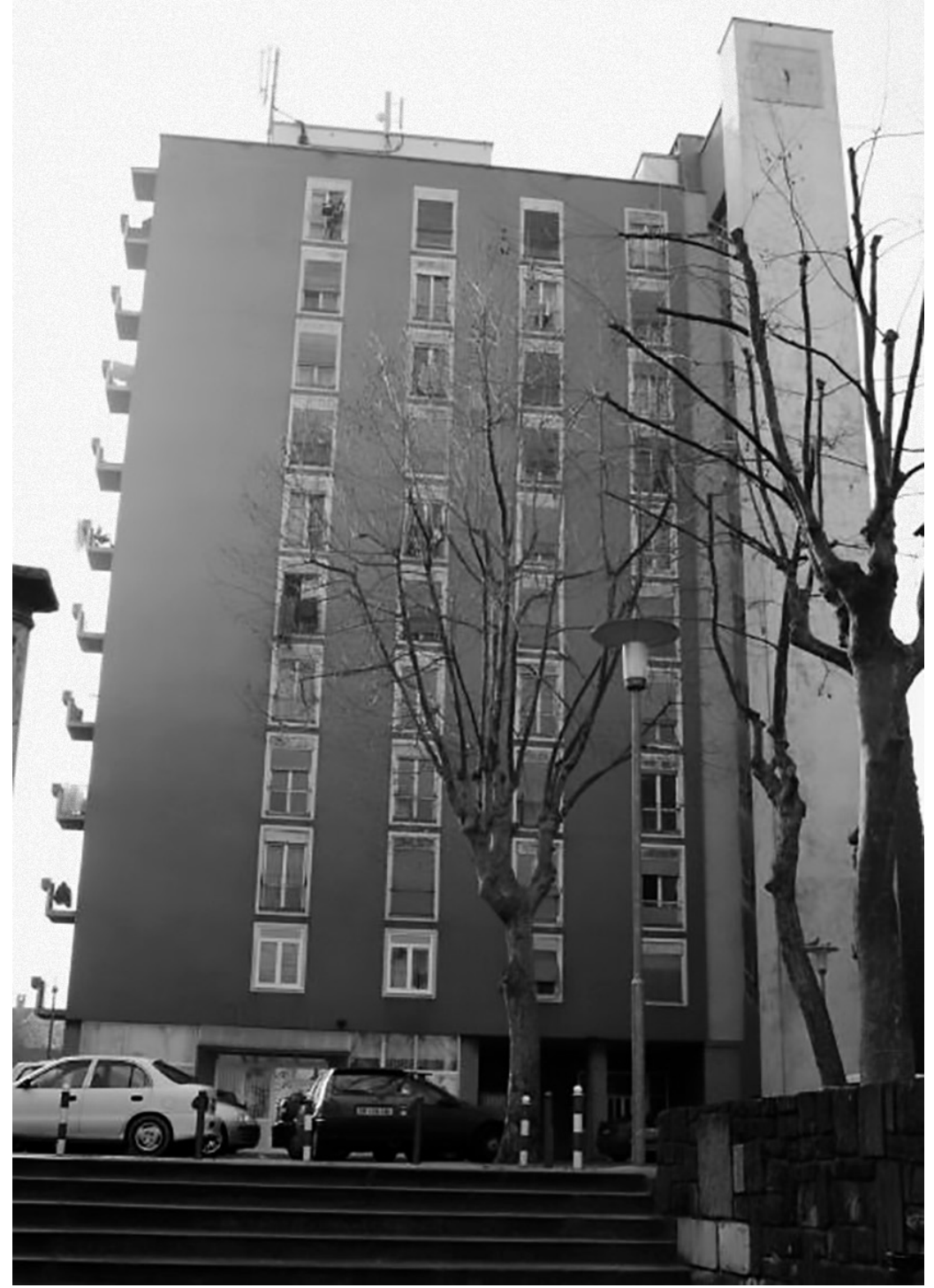

Photo: Neža Čebron Lipovec 2007 
As can be seen, sitting on the peak of the former island of the Venetian medieval town Koper/Capodistria, the red skyscraper of workers' flats has dominated the cityscape since 1960, "announcing the Slovene presence on the Adriatic" (Kresal 2016: 85). On the other side of the Gulf of Trieste, on the Karst boundary, next to the Slovene village of Prosek/Prosecco, the Sanctuary of St. Mary (Svetišče na Vejni / Santuario mariano di Monte Grisa) was built in 1963-1967.

Fig. 8: Landmark - Sanctuary of St. Mary (Svetišče na Vejni / Santuario mariano di Monte Grisa) next to the Slovene village of Prosek/Prosecco, architect Agostino Guacci, built 1963-1967

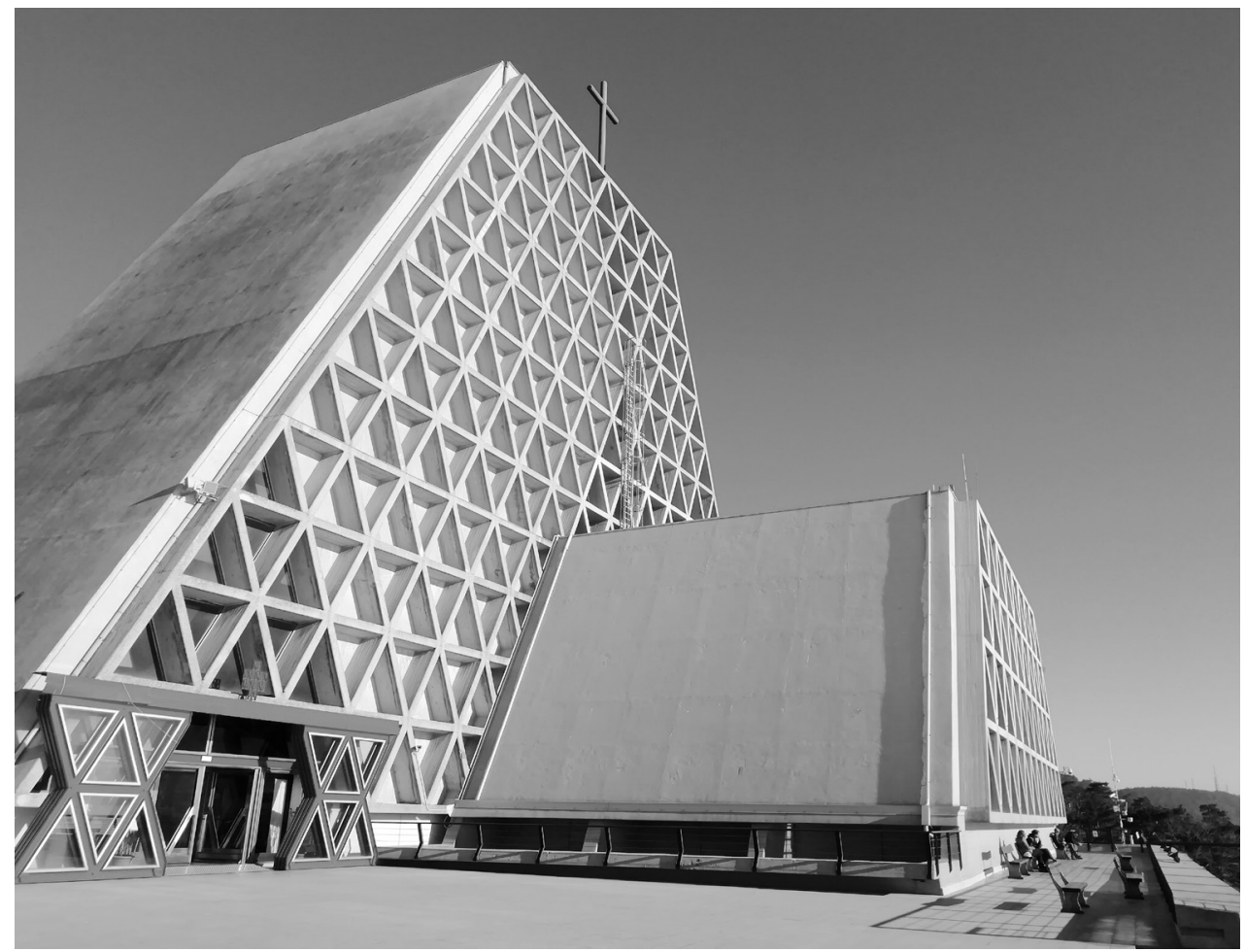

Photo: Neža Čebron Lipovec 2018

The idea was conceived by the former Bishop of Koper/Capodistria and Bishop of Trieste, Antonio Santin (Walcher 1989: 7-10). Officially, the edifice was related to consecration of the Italian nation to the immaculate heart of the Virgin. However, the idea had been conceived as early as 1945, when Bishop Santin took a vote to build it to honour the Virgin Mary for saving Trieste from the threat of destruction that was menacing the city at the end of the war (ibid.: 7), namely the arrival of Communism. The Church played a key role in constructing the Italian identity of the new settlements, since the priests that had fled from Istria to Trieste were the "keepers of the 
historic memory of the esuli"; the figures of Bishop Santin, an Istrian, and Radossi, the former Bishop of Pula/Pola, were the identity references for the Italian refugee community (Volk 1997: 243-244).

A collection of religious artworks on Istrian and Dalmatian culture was installed inside the sanctuary, exposing its role as the monument of the esuli. Placed next to the Slovene villages, known for their partisan and communist affiliation, the church represents a symbol of the Italian appropriation of the territory. Its position as a "lighthouse" turned towards the "lost Istria" also seems to (re)appropriate the land it is facing. Conversely, the Tomos skyscraper in Koper, placed on the highest peak of the former island, faces northwest, towards the "lost Trieste". This symbolic confrontation is thus not only ethnic, but clearly ideological: the Christian monument versus the Communist landmark.

\section{CONCLUSION}

Having given an overview of the main planning phases of the two "capitals" on both sides of the new post-war Slovenian-Italian border - Koper and Trieste - we can endorse the notion that a parallel process was taking place between the late 1940 s and late 1960s. The urban planning on both sides of the border accompanied the ethnic bonification of the contested spaces (Volk 2003: 295): the Italianising of the hinterland of Trieste and many of its urban, mostly Slovene neighbourhoods starting in the early 1950s, and the "Slovenising" of the historic cores of the northern Istrian towns, especially of Koper/Capodistria, starting in the late 1950s, according to plans by Edo Mihevc. Urban planning thus functioned as a dispositive for promoting national and political ideologies and fixing the new identities of the split territory. Monumental architecture, as Veschambre (2008) suggests, played a crucial role in the symbolic marking of the space, with new landmarks that still today showcase this historic duel.

\section{REFERENCES}

Abram, Marco (2017). Integrating Rijeka into Socialist Yugoslavia: The Politics of National Identity and the New City's Image (1947-1955). Nationalities Papers. DOI: 10.1080/00905992.2017.1339679.

Achleitner, Friedrich (ed.) (1993). Hommage à Edvard Ravnikar: 1907-1993. Ljubljana: F. in M. Ivanšek.

Basso, Sara (2004). La città tra due piani. La città della ricostruzione: Urbanistica, edilizia sociale e industria a Trieste, 1945-1957 (ed. Paola Di Biagi, Elena Marchigiani, Alessandra Marin). Trieste: Edizioni Comune di Trieste, 30-41. 
Beltram, Julij (1986). Pomlad v Istri: Istrsko okrožje cone B Svobodnega tržaškega ozemIja 1947-1952. Koper: Lipa; Trst: Založništvo tržaškega tiska.

Cardin, Antonia (2004). Una difficile transizione: Politiche per una città di confine. La città della ricostruzione: Urbanistica, edilizia sociale e industria a Trieste, 1945-1957 (ed. Paola Di Biagi, Elena Marchigiani, Alessandra Marin). Trieste: Edizioni Comune di Trieste, 20-29.

Corni, Gustavo (2015). Commentary. At Home but Foreigners: Population Transfers in 20th Century Istria (eds. Katja Hrobat Virloget, Catherine Gousseff, Gustavo Corni). Koper: Annales, 15-24.

Čebron Lipovec, Neža (2018). Izgradnja slovenskih obalnih mest v času po drugi svetovni vojni: Primer mesta Koper. Doktorska disertacija. Koper: Fakulteta za humanistične študije, Univerza na Primorskem.

Di Biagi, Paola (ed.) (2001). La grande ricostruzione, il piano INA-casa e I'Italia degli anni Cinquanta. Roma: Donzelli.

Di Biagi, Paola (2004). Ricostruire un'idea di città. La città della ricostruzione: Urbanistica, edilizia sociale e industria a Trieste, 1945-1957 (ed. Paola Di Biagi, Elena Marchigiani, Alessandra Marin). Trieste: Comune, 10-19.

Elman Zarecor, Kimberley (2014). Czechoslovakia's Model Housing Developments: Modern Architecture for the Socialist Future. Sanctioning Modernism: Architecture and the Making of Postwar Identities (eds. Timothy Parker, Monica Penick, Vladimir Kulić). Austin: University of Texas Press, 66-89.

Halbwachs, Maurice (2001 [1950]). Kolektivni spomin. Ljubljana: Studia Humanitatis.

Hepburn, Anthony (2004). Contested Cities in the Modern West: Ethnic and Intercommunity Conflict. London: Palgrave Macmillan.

Hrobat Virloget, Katja (2015). Breme preteklosti: Spomini na sobivanje in migracije v slovenski Istri po drugi svetovni vojni. Acta Histriae 23/3, 531-554.

Hrobat Virloget, Katja, Čebron Lipovec, Neža (2017). Heroes we Love?: Monuments to the National Liberation Movement in Istria Between Memories, Care, and Collective Silence. Studia ethnologica Croatica 29, 45-71.

Kalc, Aleksej (2015). The Other Side of the "Istrian Exodus": Immigration and Social Restoration of Slovenian Coastal Towns in the 1950s. Migration in and out of East and Southeast Europe: Values, Networks, Well-Being (paper presented at Third Annual Conference of the Institute for East and Southeast European Studies (IOS), Regensburg, July 2-4, 2015; accessible via academia.edu).

Klabjan, Borut (2016). "Our Victims Define Our Borders": Commemorating Yugoslav Partisans in the Italo-Yugoslav Border. East European Politics and Societies: and Cultures 31/2: 290-310.

Klabjan, Borut (2017). Erecting Fascism: Nation, Identity, and Space in Trieste in the First Half of the Twentieth Century. Nationalities Papers. DOI: 10.1080/00905992.2017.1313216

Krečič, Peter, Mušič, Marko, Zupan, Gojko (1996). Edvard Ravnikar - arhitekt, urbanist, oblikovalec, teoretik, univerzitetni učitelj in publicist. Ljubljana: Arhitekturni muzej. 
Križman, Marjan (1997). Nova obalna podjetja v letu 1947: Zbornik Primorske novice 50 let (ur. Slobodan Valentinčič). Koper: Primorske novice, 117.

Marchigiani, Elena (2002). Spazi e progetti. Una rassegna. Trieste '900: Edilizia sociale, urbanistica, architettura: Un secolo dalla fondazione dell'Ater (ed. Paola Di Biagi, Elena Marchigiani, Alessandra Marin). Cinisello Balsamo: Silvana Editoriale, 236-385. Marchigiani, Elena (2004). Una lunga emergenza abitativa. La città della ricostruzione: Urbanistica, edilizia sociale e industria a Trieste, 1945-1957 (ed. Paola Di Biagi, Elena Marchigiani, Alessandra Marin). Trieste: Edizioni Comune di Trieste, 42-71.

Marin, Alessandra (2012). Progetti, città, identità: Spazi urbani e ideologie nazionali a Trieste tra XIX e XX secolo. Acta Histriae 20/4, 615-630.

Mihevc, Edo (1963). Piano regolatore della costa slovena. Casabella-continuità 280, 40-53.

Mihevc, Edo (1964). Regionalni plan Slovenačke obale. Arhitektura Urbanizam 29, 329. Mumford, Eric (2000). The CIAM Discourse on Urbanism, 1928-1960. Cambridge Massachussets: MIT Press.

Pirjevec, Jože (2008). »Trst je naš!» Boj Slovencev za morje (1848-1954). Ljubljana: Nova revija.

Plesničar Gec, Ljudmila (2002). Spomini na moje delo v koprskem muzeju. 90 let Pokrajinskega muzeja Koper: 1911-2001 (ur. Jože Hočevar). Koper: Pokrajinski muzej, 104-108.

Pozzetto, Marko (1997). Maks Fabiani - Vizija prostora. Kranj: L.I.B.R.A.

Purini, Piero (2010). Metamorfosi etniche: I cambiamenti di popolazione a Trieste, Gorizia, Fiume e in Istria. 1914-1975. Udine: Kappa Vu.

Ramšak, Jure (2015). Ab initio: Moderne ideologije in izgradnja novega urbanega prostora: Zgodovina, arhitektura in perspektive kulturnega turizma v Novi Gorici in Raši. Koper: Univerzitetna založba Annales.

Rogoznica, Deborah (2011). Iz kapitalizma v socializem: Gospodarstvo cone B Svobodnega tržaškega ozemlja: 1947-1954. Koper: Pokrajinski arhiv.

Rotar, Drago (1980). Pomeni prostora (ideologije v arhitekturi in urbanizmu). Ljubljana: Delavska enotnost.

Sezneva, Olga (2003). Dual History: The Politics of the Past in Kalinigrad, Former Königsberg: Composing Urban History and the Constitution of Civic Identities (eds. John Czaplicka, Blaire A. Ruble, Lauren Crabtree). Washington: Woodrow Wilson Center Press, 58-85.

Steinacher, Gerald (2013). Fascist Legacies: The Controversy over Mussolini's Monuments in South Tyrol. University of Nebraska - Lincoln, Faculty Publications, Department of History, 144, http://digitalcommons.unl.edu/historyfacpub/144 (12. 8. 2017).

Šuligoj, Metod (2015). Nekatere ključne okoliščine (preteklega) razvoja turizma v Istri: Retrospektiva turizma Istre (ur. Metod Šuligoj). Koper: Založba Univerze na Primorskem, 17-48.

Terčon, Nadja (2015). Usidrali smo se na morje: Vzpostavitev slovenskega pomorstva 1945-1958. Piran: Pomorski muzej. 
Ther, Phillip, Siljak, Ana (2001). Redrawing Nations: Ethnic Cleansing in East-Central Europe, 1944-1948. Lanham: Rowman \& Littlefield Publishers.

Titl, Julij (1961). Populacijske spremembe v Koprskem primorju: Koprski okraj bivše cone B. Koper: J. Titl.

Ukmar, Dragica (1993). Začetki gradnje Nove Gorice. Kronika: Časopis za slovensko krajevno zgodovino XLI/2, 18-37.

Veschambre, Vincent (2008). Traces et mémoires urbaines: Enjeux sociaux de la patrimonialisation et de la destruction. Rennes: PUR.

Volk, Sandi (1997). Italijanski begunci iz Istre kot subjekt "propagande italijanstva« V Italiji in »nacionalne bonifikacije« v Trstu v letih 1945-1954. Zgodovinski časopis $51 / 2,107,241-254$.

Volk, Sandi (2003). Istra v Trstu: Naselitev istrskih in dalmatinskih ezulov in nacionalna bonifikacija na Tržaškem 1945-1966. Koper: Univerza na Primorskem, Znanstveno-raziskovalno središče; Zgodovinsko društvo za južno Primorsko.

Volk, Sandi (2004). Esuli a Trieste: Bonifica nazionale e rafforzamento dell'italianità sul confine orientale. Udine: Kappa Vu.

Walcher, Maria (1989). Il Tempio mariano di Monte Grisa: La storia e l'architettura. Trieste: Italo Svevo.

Wingfield, Nancy (2000). The Politics of Memory: Constructing National Identity in the Czech Lands, 1945 to 1948. East European Politics and Societies 14/2, 246-267.

Žitko, Salvator (2012). Glagoljaški samostan v Kopru. Annales: Series historia et sociologia 22/2, 523-532.

\section{ARCHIVAL SOURCES}

Koper Regional Archive, SI PAK KP 865, Edo Mihevc collection

Koper Regional Archive, SI PAK KP 24 OLO Koper, Minutes of Urban Planning Council meetings 


\section{POVZETEK}

\section{POVOJNI URBANIZEM OB SPORNI MEJI: NEKAJ OPAŽANJ O KOPRU/CAPODISTRIA IN TRSTU/TRIESTE Neža ČEBRON LIPOVEC}

V arhitekturnozgodovinskem prispevku avtorica obravnava urbanistične posege po drugi svetovni vojni, ko je imelo v kontekstu vzpostavljanja dveh političnih blokov (demokratično-kapitalistični Zahod in socialistični Vzhod) ter vzpostavljanja novih nacionalnih držav vprašanje razdelitve ozemlja med Italijo in Jugoslavijo mednarodne razsežnosti. Hkrati avtorica opazuje urbanistične prijeme na obeh straneh meje (predvsem v Kopru in Trstu) in jih, v povezavi s premiki prebivalstva, interpretira s konceptom »simbolnega označevanja prostora« (Veschambre 2008). V prvem povojnem obdobju, ko je zaživelo začasno Svobodno tržaško ozemlje (1947-1954) s conama A in B, so že začeli nastajati prvi načrti. Na jugoslovanski strani je arhitekt Edvard Ravnikar v obdobju 1948-1949, ko je bila gradbena dejavnost v coni B še zmerna, oblikoval idejni načrt njenega razvoja. $V$ coni A pa se je intenzivna gradbena dejavnost začela s pozidavo novih naselij (borghi) za istrske begunce na slovenskem etničnem območju v ruralnem zaledju Trsta (Vovk 2003). Že leta 1953 je začel nastajati velikopotezni načrt uveljavljenega arhitekta Maksa Fabianija za razvoj Trsta kot širšega urbanega območja (od izliva Soče do Pirana); načrt je snoval z novoizvoljenim proitalijanskim tržaškim županom Giannijem Bartolijem.

Raznolike politične vizije razdelitve prostora so vplivale tudi na posege v prostor, tako je bil na območju Kopra v času STO razvoj predviden predvsem na terrafermi, torej proč od zgodovinskega jedra. Dokončna razdelitev ozemlja po Londonskem memorandumu (1954) je sprožila velike prostorske spremembe, ki so spremljale globoke etnične metamorfoze (Purini 2010). Po zadnjem eksodusu nekdanjih prebivalcev istrskih mest (1956) in ob intenzivnem priseljevanju Slovencev iz drugih pokrajin se je začel veliki razvoj »slovenske obale« s Koprom na čelu. Arhitekt Edo Mihevc, avtor prvega celovitega regionalnega načrta (1959/1961/1963), usmerjenega v turizem, je zasnoval povsem novo regionalno modernistično arhitekturo, ki pa je zahtevala množične rušitve historičnega tkiva. Skoraj hkrati je tik ob meji, v Žavljah, moderno, regionalno uglašeno novo naselje Borgo San Sergio načrtoval tudi vodilni italijanski arhitekt Ernesto Nathan Rogers. Poteze nacionalnega in ideološkega označevanja prostora, izvedene na obeh straneh meje, danes simbolizirata Tomosova stolpnica v starem Kopru in svetišče na Vejni pri Proseku. 